\title{
Static headspace gas chromatographic determination of hexanal as a marker of lipid oxidation in fat-rich food
}

\author{
Vida Vičkačkaitė*, \\ Gintarè Pipiraitè, \\ Vilius Poškus, \\ Ingrida Jurkutè, \\ Birutė Bugelytė \\ Department of Analytical \\ and Environmental Chemistry, \\ Vilnius University, \\ 24 Naugarduko Street, \\ 03225 Vilnius, Lithuania
}

\begin{abstract}
Static headspace gas chromatographic method for determination of hexanal as a marker of lipid oxidation was developed. Tetradecane was suggested as a matrix for hexanal release from the sample. Sample equilibration temperature and time, tetradecane volume, injection time were optimized. Benzaldehyde was selected as an internal standard. Under the optimized conditions quality parameters were determined. The calibration curve was linear in the concentration range from $25 \mu \mathrm{g} \mathrm{l}^{-1}$ to $2 \mathrm{~g} \mathrm{l}^{-1}$, the detection limit was $15 \mu \mathrm{g} \mathrm{l}^{-1}$, RSD was determined by five replication analysis with hexanal concentration $0.1 \mathrm{~g}^{-1}$ and was $1.2 \%$. The technique was applied for hexanal determination in potato chips and fried potatoes.
\end{abstract}

Keywords: hexanal, static headspace gas chromatography, fat-rich food

\section{INTRODUCTION}

Lipid oxidation is a process where unsaturated fatty acids react with molecular oxygen via a free radical mechanism or in a photosensitized oxidation process [1]. As a consequence, intermediate oxidation products hydroperoxides are formed. Later on, they decompose to volatile secondary oxidation products such as alkanes, alkenes, aldehydes, ketones, alcohols, esters, acids and hydrocarbons [1, 2]. Oxidation occurs during storage and especially during heat treatment. It has a negative impact on the quality of fat-rich food because results in rancidity, off-flavours, in the formation of cytotoxic, genotoxic or neurotoxic compounds, can increase propensities to various cardiovascular and metabolic diseases [3-7].

\footnotetext{
* Corresponding author. Email:vida.vickackaite@chf.vu.lt
}

Peroxide value, $p$-anisidine value, carbonyl value, polar compounds and polymerized triacylglycerols are indexes of the deterioration of edible fats and oils [8]. However, determination of all those indexes is tedious and time consuming. Another approach for oxidation level evaluation is to select a marker the concentration of which is proportional to lipid oxidation degree. Hexanal seems to be a suitable marker as it is the main secondary oxidation product of linoleic acid which is one of the principle fatty acids of many edible oils [1, 9-13].

One of the most frequently used methods for hexanal determination is gas chromatography (GC). However, food matrices contain high molecular weight, non-volatile molecules that can remain in the GC system and result in poor analytical performance. Because of that the compounds of interest should be separated from the unwanted nonvolatile matrix. Traditional extraction techniques 
such as liquid extraction or Soxhlet extraction are time consuming. A perfect choice for hexanal determination is static headspace sampling combined with gas chromatography. Static headspace gas chromatography (SHS-GC) includes isolation of a volatile analyte in the headspace and subsequent automatic delivery of an aliquot of vapour to the GC system. SHS-GC is considered to be the fastest and cleanest method for analysing volatile organic compounds in solid or liquid matrices [14-17].

For SHS extraction of hexanal from solid matrices, water is usually used to disperse the matrix and to prepare calibration solutions of hexanal [1, 18-20]. To promote the transfer of volatile analyte into the headspace, the sample should be heated. However, heating temperature should not be set above the boiling point of the solvent, otherwise the vapour pressure becomes too great and leakages can occur or the vial could even burst. Replacing of water with a less volatile solvent should enable one to increase heating temperature, to drive the equilibrium in favour of the gas phase and thus to obtain lower detection limits of the analyte.

The aim of the work was to select an adequate static headspace extraction solvent and to develop a sensitive, fast, reliable and reproducible SHS-GC technique for determination of hexanal as an oxidation indicator in fat-rich food.

\section{EXPERIMENTAL}

\section{Reagents and samples}

Hexanal (98\%) and benzaldehyde (99\%) were purchased from Alfa Aesar (Germany). n-Tetradecane (99\%) was purchased from Sigma-Aldrich (Germany). Hexanal stock solutions (10 $\left.\mathrm{g} \mathrm{l}^{-1}\right)$ were prepared in n-tetradecane. Working hexanal solutions were diluted with n-tetradecane to a required concentration.

Potato chips 'Estrella' (Estrella Baltics, Lithuania) were purchased in a local supermarket. Fried potatoes were purchased in a local restaurant.

\section{Sample preparation}

$1 \mathrm{~g}$ of a grinded sample was placed into a $20 \mathrm{ml}$ headspace vial and $2 \mathrm{ml}$ of a $100 \mathrm{mg} \mathrm{l}^{-1}$ benzaldehyde solution in tetradecane was added. The vial was hermetically capped, ultrasonicated for $10 \mathrm{~min}$ and subjected for headspace gas chromatographic analysis.

\section{Instrumentation and conditions}

Headspace gas chromatographic analysis was performed on a PerkinElmer Clarus 580 series gas chromatograph (PerkinElmer, USA) equipped with a flame ionisation detector (temperature $250^{\circ} \mathrm{C}$, hydrogen flow $40 \mathrm{ml} \mathrm{min}^{-1}$, air flow $400 \mathrm{ml} \mathrm{min}^{-1}$, auxiliary gas (helium) flow $30 \mathrm{ml} \mathrm{min}^{-1}$ ). The GC system was equipped with the Elite 200 capillary column $(30 \mathrm{~m} \times 0.25 \mathrm{~mm}$ id, $0.25 \mu \mathrm{m}$ film thickness) (PerkinElmer, USA). Headspace extraction and sample introduction was performed on a PerkinElmer Headspace Sampler Turbomatrix 16 (PerkinElmer, USA) equipped with a balanced pressure system. Twenty millilitre headspace vials were used in all experiments. A headspace vial was positioned in the HS autosampler and equilibrated at selected temperature. The needle temperature and the transition line temperature was $10^{\circ} \mathrm{C}$ higher than the headspace vial equilibration temperature. The settings of the headspace sampler were $1 \mathrm{~min}$ for pressurization and $0.07 \mathrm{~min}$ for injection. Helium was employed as a carrier gas with 16.7 psi column head pressure. The injector temperature was held at $110^{\circ} \mathrm{C}$. The $\mathrm{GC}$ oven temperature was programmed as follows: $40^{\circ} \mathrm{C}$ for $1 \mathrm{~min}$ and from 40

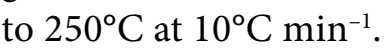

\section{RESULTS AND DISCUSSION}

\section{Headspace method development}

A selection of a suitable matrix for hexanal release is one of the most important steps of the optimization of hexanal headspace extraction conditions. As it was mentioned above, for hexanal quantification in fat-rich solid samples, water is usually used to extract the analyte and to prepare calibration solutions. However, in the case of water in order to avoid leakages and possible vial burst, equilibration temperature must be lower than $100^{\circ} \mathrm{C}$. Moreover, in the case of a volatile solvent, a significant quantity of its vapour is transferred to the headspace. Because of that hexanal is pushed from the headspace to a solution and its concentration in the headspace decreases.

Here we suggest to replace water with n-tetradecane. Tetradecane is less volatile (boiling point is $253^{\circ} \mathrm{C}$ ) thus enables one to apply higher equilibration temperature and at the same time to have a relatively small amount of the solvent vapour in 
the headspace. Moreover, more efficient extraction of hexanal from oily solid matrices should be reached as hydrophobic tetradecane easily penetrates a fat-rich matrix.

For static headspace extraction, sample heating temperature is one of the main parameters to be optimized. For this hexanal content was determined at different equilibration temperatures $\left(90-200^{\circ} \mathrm{C}\right)$, using $1 \mathrm{ml}$ of the solution of hexanal in $\mathrm{n}$-tetradecane $\left(0.1 \mathrm{~g} \mathrm{l}^{-1}\right)$ and keeping $10 \mathrm{~min}$ equilibration time.

Under these conditions the content of hexanal in the headspace permanently increased. On the other hand, it was determined that when sunflower oil and olive oil were heated above $110^{\circ} \mathrm{C}$ temperature, the hexanal content increased because of the degradation of linoleic acid that is a precursor of hexanal (Fig. 11). Based on these results the maximum equilibration temperature that does not generate hexanal formation was determined to be $110^{\circ} \mathrm{C}$. This temperature was chosen as optimal for further work.

Solvent amount has an influence on the analytes concentration in the headspace. An increase in solvent volume can improve the extraction of hexanal from a solid matrix. On the other hand, diffusion of the analyte through a thick layer of a solvent can require longer equilibration time. It was decided that a reasonable equilibration time should not exceed $30 \mathrm{~min}$. Thus from 0.5 to $5 \mathrm{ml}$

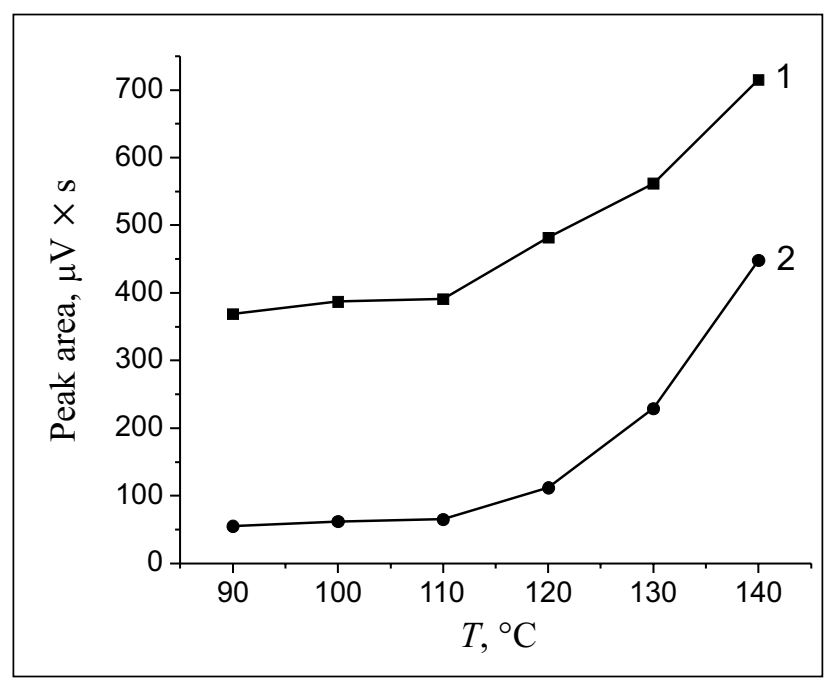

Fig. 1. Influence of the temperature on the hexanal peak area in sunflower oil (1) and olive oil (2) heated at different temperatures for $10 \mathrm{~min}$ and then equilibrated at $90^{\circ} \mathrm{C}$ for $10 \mathrm{~min}$. Injection time $0.03 \mathrm{~min}$ of n-tetradecane containing $0.1 \mathrm{~g} \mathrm{l}^{-1}$ of hexanal was equilibrated at $110^{\circ} \mathrm{C}$ temperature for $30 \mathrm{~min}$.

The results demonstrated (Fig. 2) that for the $1.5-5 \mathrm{ml}$ solution volume hexanal peak areas were quite stable and a slight decrease in the peak area was observed only up to the $1.5 \mathrm{ml}$ liquid phase volume. It can be explained by a high

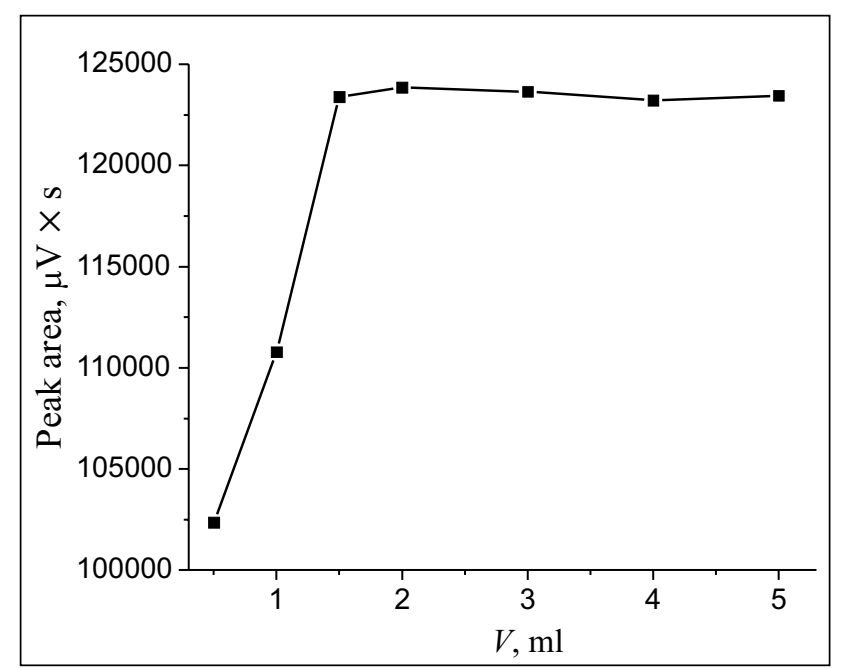

Fig. 2. Influence of the solution volume on the hexanal content in the headspace. Hexanal concentration in tetradecane $0.1 \mathrm{~g} \mathrm{l}^{-1}$, equilibrated at $110^{\circ} \mathrm{C}$ temperature for $30 \mathrm{~min}$. Injection time $0.03 \mathrm{~min}$

solubility of hexanal in tetradecane. It is known that the concentration of a compound in the headspace vapour phase is proportional to its original concentration in the sample and the reciprocal of the partition coefficient $\mathrm{K}$ of the analyte between the liquid phase and the gas phase added to the phase ratio $\beta$ [21]. If $K$ is low (the compound prefers the headspace phase), then the value of $\beta$ (hence the sample volume) significantly affects the concentration in the headspace phase. Contrarily, in the case of a compound with a high partition coefficient the effect of changing the sample volume makes a little difference to the concentration in the headspace vapour. Hexanal is very soluble in tetradecane, thus its partition coefficient between the tetradecane phase and gas phase is high resulting in a minor effect of the liquid phase volume on the concentration of the analyte in the headspace. For further work $2 \mathrm{ml}$ of the liquid phase has been chosen and equilibration time for this liquid phase volume has been determined.

The results presented in Fig. 3 demonstrate that the hexanal peak area has maximized at about 


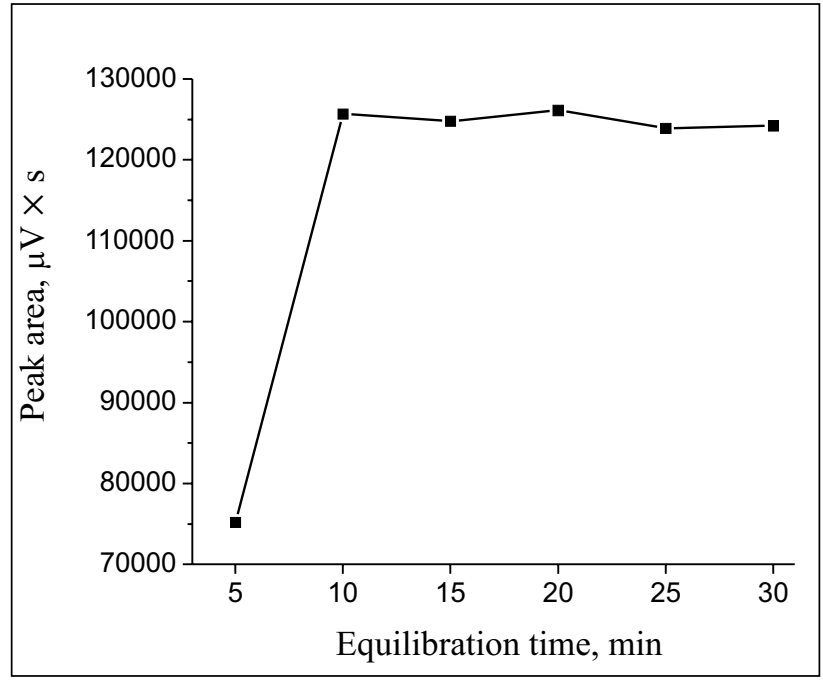

Fig. 3. Influence of the equilibration time on the hexanal peak area. Solution volume $2 \mathrm{ml}$. Hexanal concentration in tetradecane $0.1 \mathrm{~g} \mathrm{l}^{-1}$, equilibrated at $110^{\circ} \mathrm{C}$ temperature. Injection time $0.03 \mathrm{~min}$

10 min and after remained stable. The optimum equilibration time was set to $12 \mathrm{~min}$, to allow for possible variations in the heat transfer into the vial.

Further, a volume of the gas phase injected to GC has been optimized. The more gas phase injected, the bigger peak of hexanal should be observed. On the other hand, with the increase of injected gas phase volume, peaks can broaden and tail. We used an equipment supplied by pressure balanced sampling that allows direct control of the time width of the vapour plug entering the GC column. Injection time widths from 0.01 to 0.2 min have been examined using a hexanal solution in $\mathrm{n}$-tetradecane $\left(0.1 \mathrm{~g} \mathrm{l}^{-1}\right)$. The results presented in Fig. 4 demonstrate that at low injection times peak area and height proportionally increase with the injection time and the efficiency starts to decrease notably when the injection time exceeds $0.08 \mathrm{~min}$. The peak area correlation coefficient is bigger than 0.99 up to $0.15 \mathrm{~min}$ injection time. Peak height linearity is more sensitive to the injection time and at $0.08 \mathrm{~min}$ is less than 0.99 (its value is 0.9827 ). Based on the results, in order to establish the optimal conditions for maximum recovery of volatile compounds without a loss of efficiency, $0.07 \mathrm{~min}$ injection time was chosen.

In order to achieve a better repeatability of the results benzaldehyde was selected as an internal standard. Under the optimized conditions quality parameters were determined. The calibra-

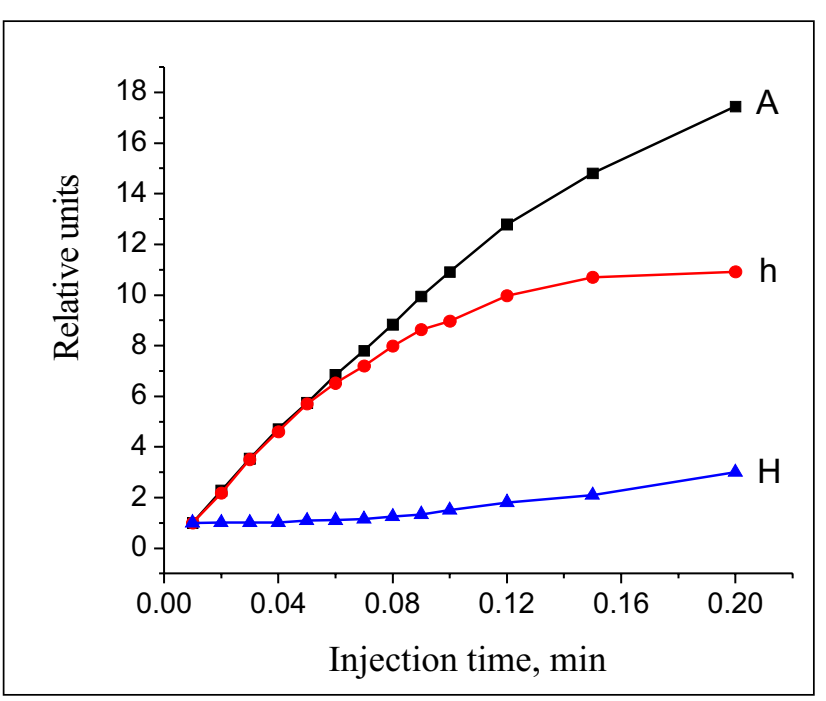

Fig. 4. Relative hexanal peak area (A), height (h) and theoretical plate height $(\mathrm{H})$ dependence on the injection time. Parameters at $0.01 \mathrm{~min}$ are considered equal to 1 . Hexanal concentration $0.1 \mathrm{~g} \mathrm{l}^{-1}$, equilibrated at $110^{\circ} \mathrm{C}$ temperature for $10 \mathrm{~min}$

tion curve was drawn with 8 calibration points with three replicate injections and was linear in the concentration range from $25 \mathrm{\mu g} \mathrm{l}^{-1}$ to $2 \mathrm{gl}^{-1}$ with the correlation coefficient 0.9994 . The limit of detection was calculated as three times the baseline noise and was $15 \mu \mathrm{g} \mathrm{l}^{-1}$. The relative standard deviation was determined by five replication analysis of the sample with hexanal concentration $0.1 \mathrm{~g} \mathrm{l}^{-1}$ and was $1.2 \%$.

\section{Real sample analysis}

The developed SHS-GC method was applied for hexanal determination in potato chips and fried potatoes. $1 \mathrm{~g}$ of a grinded sample was placed into a $20 \mathrm{ml}$ headspace vial and $2 \mathrm{ml}$ of a $0.1 \mathrm{~g} \mathrm{l}^{-1}$ benzaldehyde solution in tetradecane was added. The vial was hermetically capped, ultrasonicated for $10 \mathrm{~min}$ and subjected for headspace gas chromatographic analysis.

A chromatogram of potato chips headspace is presented in Fig. 5. Quantification was carried out using the standard addition method. The results demonstrated that the concentration of hexanal in the examined potato chips was close to that obtained by other researchers [1, 9] and was $1.2 \mathrm{mg} \mathrm{kg}^{-1}(\mathrm{RSD}=3.8 \%, n=3)$.

Fried potatoes obtained from a local restaurant were also analysed using the prepared method. The analysis revealed that fried potatoes contained $280 \mathrm{mg} \mathrm{kg}^{-1}$ of hexanal (RSD $=4.2 \%, n=3$ ). Such a big quantity of hexanal suggests that the edible 


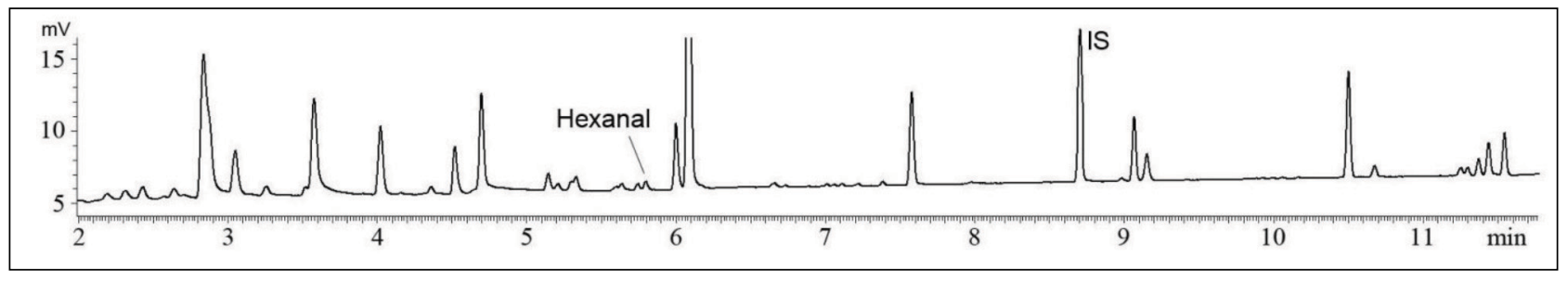

Fig. 5. Chromatogram of chips extract. For SHS-GC conditions see Instrumentation and conditions

oil for potatoes frying was heated at elevated temperatures for a long time.

\section{CONCLUSIONS}

The static headspace gas chromatographic method for hexanal determination was improved by applying n-tetradecane as an extraction solvent and a solvent for calibration solutions of hexanal. Before, for hexanal quantification in fat-rich solid samples, water was usually used to extract the analyte and to prepare calibration solutions. Replacement of water with less volatile $n$-tetradecane enabled an efficient extraction of hexanal from oily solid matrices, application of higher equilibration temperature, ensured a small amount of the solvent vapour in the headspace and thus low detection limits of hexanal.

At optimized extraction conditions the sensitivity of the suggested method is quite satisfactory to determine hexanal as a marker of edible oil oxidation in fat-rich solid samples such as potato chips and fried potatoes.

Received 12 February 2020 Accepted 2 March 2020

\section{References}

1. M. H. Azarbad, H. Jelen, Food Anal. Methods, 8, 1727 (2015).

2. L. Sghaier, J. Vial, P. Sassiat, et al., Eur. J. Lipid Sci. Technol., 118, 1853 (2016).

3. S. Babaee, A. Daneshfar, Anal. Methods, 10, 4162 (2018).
4. H. R. Katragadda, A. Fullana, S. Sidhu, Á. A. Carbonell-Barrachina, Food Chem., 120, 59 (2010).

5. N. Gotoh, H. Watanabe, R. Osato, A. Iwasawa, K. Inagaki, S. Wada, J. Oleo Sci., 54(7), 397 (2005).

6. M. D. Guillen, P. S. Uriarte, J. Agric. Food Chem., 57(17), 7790 (2009).

7. Y. Cui, P. Hao, B. Liu, X. Meng, Food Chem., 233, 77 (2017).

8. Y. Endo, J. Oleo Sci., 67(1), 1 (2018).

9. A. Sanches-Silva, A. Rodriguez-Bernaldo de Quiros, J. Lopez-Hernandez, P. Paseiro-Losada, J. Chromatogr. A, 1046, 75 (2004).

10. S. Panseri, S. Soncin, L. M. Chiesa, P. A. Biondi, Food Chem., 127, 886 (2011).

11. F. Giuffrida, P. A. Golay, F. Destaillats, B. Hug, F. Dionisi, Eur. J. Lipid Sci. Technol., 107, 792 (2005).

12. E. Beltran, R. Pla, J. Yuste, M. Mor-Mur, Meat Science, 64, 19 (2003).

13. D. Ghirardello, M. Bertolino, S. Belviso, et al., Postharvest Biol. Technol., 112, 95 (2016).

14. A. Arezou, M. Shuhaimi, A. M. Yazid, M. Rosfarizan, Int. J. Food Prop., 12, 808 (2009).

15. H. Cheng, Crit. Rev. Food Sci., 50, 938 (2010).

16. V. Vičkačkaitè, D. Jasas, Chemija, 27(2), 109 (2016).

17. B. Kolb, L. S. Ettre, Static Headspace-Gas Chromatography: Theory and Practice, 2nd edn., Wiley, New Jersey (2006).

18. A. I. Mandic, I. J. Sedej, M. B. Sakac, A. C. Misan, Food Anal. Methods, 6, 61 (2013).

19. M. Romeu-Nadal, A. I. Castellote, M. C. LópezSabater, J. Chromatogr. A, 1046, 235 (2004).

20. T. Wenzl, E. P. Lankmayr, J. Sep. Sci., 24, 885 (2001).

21. An Introduction to Headspace Sampling in Gas Chromatography [http://citeseerx.ist.psu.edu/viewdoc/download;jsessionid=4C927F8F2082BDFED9 9465B2936847B2?doi=10.1.1.684.7251\&rep=rep 1 \&type $=\mathrm{pdf}]$. 
Vida Vičkačkaitė, Gintarė Pipiraitė, Vilius Poškus, Ingrida Jurkutė, Birutė Bugelytė

\section{RIEBALU OKSIDACIJOS INDIKATORIAUS}

HEKSANALIO NUSTATYMAS RIEBALINGAME

MAISTE STATINĖS VIRŠERDVĖS DUJŲ

\section{CHROMATOGRAFIJOS METODU}

Santrauka

Riebalu oksidacijos indikatoriui heksanaliui nustatyti pasiūlyta statinè viršerdvės dujų chromatografinè analizè. Tetradekanas pasirinktas terpe, ị kurią iš mèginio pereina heksanalis. Optimizuota méginio kaitinimo temperatūra, trukmé, tetradekano tūris ir ịleidimo trukmé. Vidiniu standartu pasirinktas benzaldehidas. Optimizuotomis sąlygomis nustatytos metodo analizinès charakteristikos: kalibracinè kreivè tiesinè $25 \mu \mathrm{g} \mathrm{l}^{-1}-2 \mathrm{~g} \mathrm{l}^{-1}$ heksanalio koncentracijų intervale, ap-

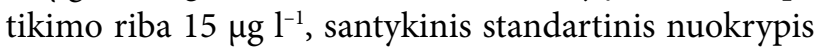
esant heksanalio koncentracijai $0,1 \mathrm{~g} \mathrm{l}^{-1}$ ir atlikus penkis matavimus yra $1,2 \%$. Sukurta metodika pritaikyta heksanaliui nustatyti bulvių traškučiuose ir keptose bulvèse. 